\title{
DEVELOPMENT OF PROFESSIONAL SELF-DETERMINATION OF TEENAGERS
}

\author{
Valeriya Milyaeva \\ Borys Grinchenko Kyiv University, Ukraine \\ Iryna Kalyuzhna \\ Borys Grinchenko Kyiv University, Ukraine \\ Zoryana Burkovska \\ Lviv Stepan Gzhytskyi National University of Veterinary Medicine and Biotechnologies, \\ Ukraine \\ Svitlana Lozynska \\ Lviv Ivan Franko National University, Ukraine

\section{Iryna Voloshanska} \\ Drohobych Ivan Franko State Pedagogical University, Ukraine
}

\begin{abstract}
The article dwells on the problem of teenagers' professional self-determination as the readiness to making choice of the profession. Psychological factors of professional selfdetermination of high school students are defined and theoretically substantiated. Psychological properties are investigated, the means of which is the formation of factors of senior school students' professional self-determination. In our research by professional selfdetermination we mean a stable, value-oriented complex of professionally important traits and personality traits, which is characterized by a certain structure, determines the readiness of high school students to choose a profession and is formed by a number of psychological factors. We prove that the set of psychological factors of professional self-determination of high school students has a nonlinear character and multi-level structure. The purpose of the publication is to investigate the psychological factors of professional self-determination and to substantiate the need to introduce a program of psychological and pedagogical support for the development of professional self-determination of high school students. As a result of the research psychological factors of professional self-determination of high school students were established: actual motives; sufficient level of development of volitional regulation of personality; locus control; a sufficient level of the formation of reflectivity development. The conducted psycho diagnostics revealed the immaturity of psychological factors of professional self-determination among high school students; unreadiness of teenagers to make an independent, conscious professional choice. This situation requires targeted correction through the introduction of a program of psychological and pedagogical support.
\end{abstract}

Keywords: choice of profession, professional self-determination, psychological factors of professional self-determination, readiness for choice of profession, teenagers. 


\section{Introduction}

The problem of the professional self-determination development of teenagers' is urgent and caused by the need of Ukrainian society in citizens, who can who can be prepared for a conscious and independent choice of profession. In this regard it is necessary to improve vocational guidance, in particular to explore the psychological characteristics of the personality of senior schoolchildren, which are important for the choice of profession. The aim of the article is to investigate the psychological factors of professional selfdetermination and to substantiate the need to introduce a program of psychological and pedagogical support for the development of professional selfdetermination.

Professional self-determination is mostly regarded as a process in the scientific literature: the constantly changing choices that underpin the "I concept» and the problem of the freedom of personal choice in society (Zakatnov, 2001; Tytarenko, 2013; Sappa 2011); personal development in the light of the internal contradictions resolution of the personality (Shavyr, 1981); takes place over a long period and includes a series of intermediate decisions and leads to the final professional choice (Hinzburh, 1998); formation of personal attitude to the occupational work environment and the way of its selfrealization (Chystiakova, 1987); the continuous process of searching for and acquiring the meaning of one's professional activity in the light of the discovery and realization of one's «I» as a professional (Nikitina, 1998); independent and conscious finding of the meaning of performed work and all life activity (Priazhnykov, 1996) decision making by a person on the choice of future activity in the light of himself as a subject of a specific professional activity, due to self-esteem by a person of their own individual, psychological qualities and their capabilities comparison with psychological requirements for the profession (Honcharenko, 1996).

\section{Theoretical basis of the research}

The authors of the article have taken the position that the phenomenon of professional self-determination is described by the scientists as an integrative personal formation, ensuring the internal readiness of a person to choose a profession, conscious and independent construction of the desired future image, correction and realization of the prospects of their own professional development; has a corresponding structure, formed under the influence of certain psychological factors (Chystiakova, 1987; Priazhnykov, 1996; Hinzburh, 1998). Under the professional self-determination we mean a stable, valueoriented complex of professionally important personality traits, that has the 
appropriate structure, determining the readiness of senior schoolchildren to choose a profession and is formed under the influence of certain psychological factors (Kaliuzhna \& Miliaieva, 2019).

The article deals with the progress and results of establishing the psychological factors of professional self-determination of senior schoolchildren, where the factor is considered as the reason, the mover for the exercise of independent and conscious choice of profession.

In the theoretical aspect, the main internal factors of professional selfdetermination include: the presence of one's own position and conscious attitude to life (Rubynshtein, 2003); knowledge about oneself and the world of professions (Karpov, 2003; Kuznetsova, 2011); analysis of own interests, inclinations, abilities; the existence of a specific program of action for the selection and achievement of professional goals (Klymov, 2004); certain work and life experience, appropriate level of psychological maturity of the personality (Shavyr, 1981).

Researchers consider the external factors of professional self-determination of personality to be general factors of the macro-environment, its content depends on social and economic conditions of life of people, demographic development of the region, cultural, educational and professional level of the family etc. (Zakatnov, 2001; Klymov, 2004).

The authors of the article believe that the division of factors of professional self-determination only into «internal» and «external» does not reflect holistic structure. We have established that the structure of psychological factors of senior schoolchildren professional self-determination has a nonlinear complex character and is determined on the basis of the possibility of influencing the formation of factors of professional self-determination in the educational process. To the macro level belongs influenced factors minimally; to meso level - factors that can be indirectly influenced; to the micro level - the factors that can be influenced directly within the program of psychological and pedagogical support for the formation of professional self-determination of senior schoolchildren.

The structure of psychological factors of professional self-determination of senior schoolchildren includes:

- $\quad$ at the macro level - integration into the world community (formation of the global labor market); promoting of civil society; balanced state development; actual needs of the state in personnel; prestige / prestige of the profession;

- $\quad$ at the meso level - a favorable, competent position of parents; developing a subject-subjective strategy for the impact of the school environment; 
- $\quad$ at the micro level - updated motives; sufficient level of volitional regulation development; locus control; sufficient level of development of reflexivity.

The outlined theoretical principles were the basis for building an empirical research of psychological factors of professional self-determination of senior schoolchildren.

\section{Methodology}

The research was conducted among the 10-th grades senior schoolchildren of 15-16 years old of Kyiv Comprehensive School in order to identify psychological factors of professional self-determination. A control group 24 senior schoolchildren and an experimental group - 24 persons were formed to investigate the effectiveness of the program of psychological and pedagogical support for the formation of professional self-determination. Total respondents were: 330 high senior schoolchildren, 48 parents and 16 teachers.

A creative initiative group was created at the base of the school № 286 of Kyiv to carry out an empirical research consisting of: director; deputy director of educational work; psychologist; social pedagogue; tutors; teachers. Scientific support was provided by the educational and scientific center for leadership and staff development of Borys Grinchenko Kyiv University: scientific supervisor Milyaeva V.R., junior researcher - Kalyuzhna I.P.

The logistical conditions for conducting the experimental work: cabinets for testing, training sessions and individual consultations were defined; necessary training materials were prepared. An incentive material form and a response form were prepared. All the results of the research were entered in the individual psychological and pedagogical card.

In order to establish the psychological factors of professional selfdetermination, a methodological toolkit of research was determined and the senior schoolchildren were tested at the beginning and at the end of the program of psychological and pedagogical support.

Thus, the following methods were used to establish the psychological factors of professional self-determination of senior schoolchildren: the test «Motives for choosing a profession» by R. Ovcharova to determine the leading type of motivation in choosing a profession; «The level of correlation of «value» and «accessibility» in different spheres of life by E. Fantalova for the diagnosis of value orientations of personality; «Research of volitional organization of personality» by M. Hutkin, G. Mychalchenko, A. Prudylo for research of volitional sphere of personality; «Locus Control» test by J. Rotter to determine locus of control; «Diagnosis of Reflexivity» by A. Karpov to determine the level of development of reflexivity; questionary and questionnaire «Detecting 
schoolchildren's willingness to choose a profession» by V. Uspensky to determine the senior schoolchildren readiness to choose a profession. 14 psychodiagnostic techniques were used totally.

\section{Results}

The results of the research of the type of motivation in the process of choosing a profession by the method of Ovcharova R. showed choosing a profession, individually significant motives (personal importance; satisfaction that the job brings) are important for $42 \%$. For $33 \%$ of the personal and public importance of the future profession - its social and personal importance, the opportunity for communication, guidance from other people, etc. Although most responders seek to meet their own needs for future activity, a significant percentage have external positive motivation $-22 \%$. The main motives for the activities are: material incentives, prestige, work promotion, etc. $3 \%$ of responders feel pressure from the environment, fear of condemnation and failure.

Choosing a profession is seen as a means of achieving something guided by external motives. External motivation contains those motives that are outside the employee. Satisfaction with the profession and personal self-realization becomes impossible. Methodology «The level of correlation of «value» and «accessibility» in different spheres of life by E. Fantalova allows to diagnose the severity of 12 value orientations of the individual.

Despite the fact that schoolchildren are guided by external motives while choosing a profession, the majority of senior schoolchildren (82\%) hope that their values can be realized in the interesting work. In the zone of «internal vacuum» (accessible but not significant) are the following value orientations: «active life» (27\%), «beauty of nature and art» (22\%), «knowledge» (16\%), «creativity» (18\%). In a state of «internal conflict» (are less «accessible» than «valuable») - «love» (23\%), «material stability» (19\%), «freedom» (18\%), «family» (32\%). Such results are explained by the peculiarities of teenagers the desire for a sense of adulthood, that cannot be fully realized due to the age characteristics.

The results of diagnostics of volitional organization of personality by M. Hutkin, G. Mychalchenko, A. Prudylo for research of volitional sphere of personality showed that only $11 \%$ of senior schoolchildren demonstrated a high level of conscious willful self-regulation of behavior; $87 \%$ of schoolchildren had an average level of development of a volitional organization; 2\% of senior schoolchildren had a low level. In order to choose a profession consciously and independently, to be prepared to exercise professional self-determination over the course of life and the difficulties that may arise, teenagers should develop 
willpower.

In the result of the research, the dominance of senior schoolchildren of external locus of control was revealed (67\%); only 33\% of senior schoolchildren have internal locus control («Locus Control» test by J. Rotter). The obtained data indicate that a significant percentage of modern senior schoolchildren are responsible for shifting responsibility for making their professional choices and ways of their implementation to parents, teachers, friends and others. One third of senior schoolchildren are aware that choosing a profession is their responsibility.

A low level of reflectivity development was found in $40 \%$ of respondents. It testifies the difficulty of creating a rationally structured internal position, that is necessary for professional self-determination of personality. $59 \%$ of responders have an average level of reflectivity development. Only 1\% has a high level of development of reflexivity («Diagnosis of Reflexivity» by A. Karpov). The obtained results indicate the need for the development of reflexivity of senior schoolchildren to create a coherent «I-concept», reasonable self-esteem, rationally structured internal position of the personality, identity. In turn it will allow to make conscious professional choice.

Low and average levels of reflexivity lead to difficulties in identifying personal goals and finding ways to achieve them. Thus, it is revealed that $86 \%$ of the respondents have unstable, not always justified goals that are formed under the influence of the environment; while choosing a profession, responders don't have their own position, but take the position of others (parents, teachers, friends) regarding the choice of future profession. There is an inability to set design goals in $2 \%$; only $12 \%$ have conscious, personal goals, that is, goals that are conscious and shaped according to the needs, aspirations of personality («Goal-Means-Result» test by A. Karmanov).

It is grounded that $45 \%$ of senior schoolchildren have difficulties in choosing the means, $8 \%$ have a chronic lack of achievement (the lack of their own, conscious goal leads to difficulties in choosing the means to achieve it). Only 39\% have sufficient freedom to choose the means to achieve the goal. Goals adoption from the outside is a feature of adolescence. It is conditioned by the need to be recognized, belonging to a specific reference group (see Table 1). Therefore, it is important to take into account this feature of teenagers and through the group interaction to influence the formation of skills, to set real goals. The senior schoolchildren learn to take responsibility for their own lives and professional choices while developing a program of psychological and pedagogical support for the formation of professional self-determination. 
SOCIETY. INTEGRATION. EDUCATION

Proceedings of the International Scientific Conference. Volume III, May $22^{\text {th }}-23^{\text {th }}, 2020.364-373$

Table 1 Results of psychological diagnostics of the formation of psychological factors of professional self-determination of senior schoolchildren

\begin{tabular}{|c|c|c|c|}
\hline № & $\begin{array}{l}\text { Factors of professional } \\
\text { self-determination of } \\
\text { senior schoolchildren }\end{array}$ & Psychological features & $\begin{array}{l}\text { Levels of } \\
\text { development, \% } \\
(\mathrm{n}=330)\end{array}$ \\
\hline 1 & Updated motives & Individually significant motives & 42 \\
\hline 2 & Updated value orientations & $\begin{array}{l}\text { Ability to realize values in the } \\
\text { interesting work }\end{array}$ & 82 \\
\hline \multirow[t]{2}{*}{3} & \multirow{2}{*}{$\begin{array}{l}\text { A sufficient level of } \\
\text { development of volitional } \\
\text { regulation of personality }\end{array}$} & $\begin{array}{l}\text { High level of persistence } \\
\text { development }\end{array}$ & 14 \\
\hline & & $\begin{array}{l}\text { High general level of development of } \\
\text { volitional regulation of personality }\end{array}$ & 11 \\
\hline 4 & Locus of control & Internal locus of control & 33 \\
\hline \multirow[t]{4}{*}{5} & \multirow[t]{4}{*}{$\begin{array}{l}\text { A sufficient level of } \\
\text { development of reflectivity }\end{array}$} & $\begin{array}{l}\text { The average level of development of } \\
\text { reflectivity }\end{array}$ & 59 \\
\hline & & The high level of development & 1 \\
\hline & & The presence of real, own goals & 12 \\
\hline & & $\begin{array}{l}\text { Sufficient freedom to choose the } \\
\text { means to accomplish the goal }\end{array}$ & 39 \\
\hline
\end{tabular}

A regression analysis was used to determine the influence of a personality psychological properties on the willingness to make a profession. It was found that the following psychological properties have a direct influence on the willingness to make a professional choice: the internal locus of control $(+0.575)$; reflexivity $(+0,488)$; high level of development of volitional regulation $(+0.359)$; high level of persistence development (+0.327); internal individually significant motives $(+0.288)$; the presence of real, own goals $(+0,285)$; sufficient freedom to choose the means to achieve the goal $(+0.281)$. The inverse effect on the willingness to make a professional choice is an indicator of internal socially significant motives $(-0.254)$.

Non-formation of psychological factors of professional self-determination leads to unwillingness to make conscious, independent choice of profession. It has been found that only $8 \%$ of respondents are ready to make their professional choices; $37 \%$ of respondents show the average readiness; internally not ready to make a choice $-38 \% ; 17 \%$ of respondents indicate a low level of willingness to make a choice. The results of the research show the need to introduce a program of psychological and pedagogical support for the formation of professional selfdetermination of senior schoolchildren. The purpose of the program is to develop the psychological characteristics of the personality. It ensures the readiness of senior schoolchildren to make professional choices. The program is based on the following principles: consistency and continuity, comprehensiveness and systematicity, openness, correctness and balance. The 
program should include systematic work with schoolchildren, parents and teachers in three areas: psychodiagnosis, formation and development, psychoprophylaxis and psycho-correction (see Figure 1).

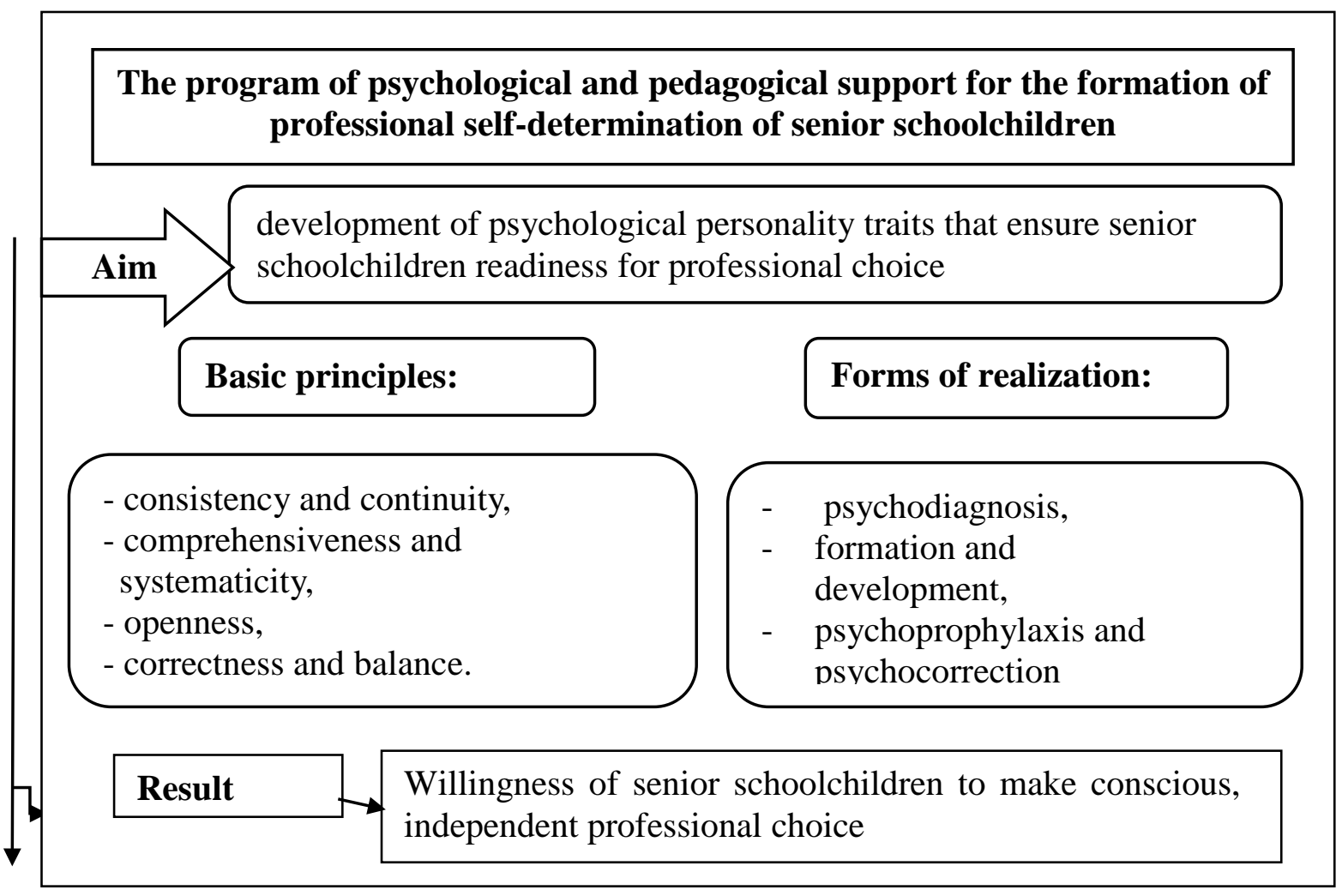

Figure 1 Structure of the program of psychological and pedagogical support for the formation of professional self-determination of senior schoolchildren

Each of these section is a preparation for the next and the continuation of the previous one. The psychodiagnostic - contains research tools for identifying the level of internal factors of professional self-determination (before and after psychological and pedagogical support) and individual diagnostics, observation, collage for work with parents and teachers.

Formation and development includes training sessions, individual consultations, facilitation sessions, workshops, seminars aimed at targeting the development of psychological factors of professional self-determination.

Psychoprophylaxis and psycho-correction were implemented in the form of individual consultations, business games, training sessions, collages, thematic circles for students, parents, teachers and aimed at providing timely support in difficult situations. 


\section{Conclusions}

The presented theoretical analysis of scientific sources in our article has shown that there are different approaches to understanding the phenomenon essence of the professional self-determination. It prompted us to give the author definition of this concept as a stable, value-oriented complex of professionally important personality traits. It has the appropriate structure, determines the willingness of senior schoolchildren to choose a profession. It is is formed under the influence of certain psychological factors.

The main attention is paid to the establishment and analysis of psychological factors of professional self-determination of senior schoolchildren: the level structure is singled out and the possibilities of direct influence on the formation of such mental properties as actualized motives are investigated; sufficient level of development of volitional regulation of personality; locus of control; a sufficient level of reflectivity development. It is established the psychological characteristics, in the light of which the factors of professional self-determination are manifested: high level of development of volitional organization of personality and perseverance; actualization of internal individually significant motives and value orientations; internal locus of control; high level of development of reflexivity, presence of real, own goals, free choice of means for realization of purpose to ensure readiness for realization of conscious and independent choice of profession.

The arguments about the need to develop and introduce into the educational process a program of psychological and pedagogical support for the formation of professional self-determination of senior schoolchildren. It is based on the laws and mechanisms of age development and also provides the development of psychological factors of professional self-determination of senior schoolchildren.

\section{Gratitude}

The authors express the gratitude for the support in conducting the research to Borys Grinchenko Kyiv University; staff and administration of Kyiv Comprehensive School № 286, where the experimental work on the theme: «Openning and developing the potential of the personality in the school environment as an tool for individualization, socialization and professionalization of senior schoolchildren» took place in 2013-2017 (Order of of Ministry of Education and Science, Youth and Sports 30.10.2013, № 814).

Particularly express the gratitude to Lebid N.K. - for comprehensive support in organizing empirical research, creative ideas and recommendations 
and Marchenko L. Yu. - for creating the necessary conditions for the implementation of research work.

\section{References}

Hinzburh, M. (1998). Lychnostnoe samoopredelenye kak psykholohycheskaia problema. Voprosbl psykholohyy, 2, 19-27.

Honcharenko, S. (1997). Ukrainskyi pedahohichnyi slovnyk. K.: Lybid.

Zakatnov, D. (2001). Tekhnolohii aktyvizatsii profesiinoho samovyznachennia starshoklasnykiv. Naukovi zapysky Ternopilskoho derzhavnoho pedahohichnoho universytetu. Seriia: Pedahohika, 6, 99-104.

Kaliuzhna, I. (2017). Teoretychnyi analiz psykholohichnykh chynnykiv profesiinoho samovyznachennia starshoklasnykiv. Humanitarnyi visnyk DVNZ «PereiaslavKhmelnytskyi derzhavnyi pedahohichnyi universytet imeni Hryhoriia Skovorody», 74, 350-359.

Kuznetsova, I. (2011). Predstavlenyia starsheklassnykov o profylnoi shkole. Sovremennaia psykholohyia: teoryia y praktyka. M.: Ynstytut stratehycheskykh yssledovanyi.

Karpov, A. (2003). Psykholohyia menedzhmenta: Ucheb. posobye dlia stud. vuzov. M.: Hardaryky.

Miliaieva, V., \& Kaliuzhna, I. (2019). Osoblyvosti psykholohichno-pedahohichnoho suprovodu profesiinoho samovyznachennia starshoklasnykiv. Problemy suchasnoi psykholohii: zb. nauk. pr. Zaporizkoho natsionalnoho universytetu ta Instytutu psykholohii imeni H.S. Kostiuka, 2(16), 79-84.

Priazhnykov, M. (1996). Professyonalnoe y lychnostnoe samoopredelenye. M.: Yzd-vo ynt praktycheskoi psykholohy. Voronezh: NPO «MODЭK».

Rubynshtein, S. (2003). Bitye y soznanye. Chelovek y myr. SPb.: Pyter.

Tytarenko, T. (2013). Suchasna psykholohiia osobystosti. 2-e vyd. K.: Karavela.

Chystiakova, S. (1987). Professyonalnaia oryentatsyia shkolnykov: orhanyzatsyia y upravlenye. Moskva.

Shavyr, P. (1981). Psykholohyia professyonalnoho samoopredelenyia $v$ rannei yunosty. M.: Pedahohyka.

Nikitina, L. (1998). Kak vospytat zdorovoho rebenka. Znanye.

Klymov, E. (2004). Psykholohyia professyonalnoho samoopredelenyia. M.: Yzdatelskyi tsentr «Akademyia».

Sappa, M. (2011). Protses profesiinoho samovyznachennia uchnivskoi molodi: modelnyi analiz. Visnyk KhNUVS, 2(53), 343-351. 